\title{
Tankens fest
}

\author{
I anledning af Martin Heideggers fortælling om Grækenland
}

\section{DORTHE JøRGENSEN}

"Vi hører hele tiden, at kunstbegrebet er forældet. At det ikke giver nogen mening at ville definere, hvad kunst er, for kunst kan være så meget. Men jeg synes, det er meget sværere at sige, hvad litteratur er," sukker studenten. "Tag nu reklamebureauerne. Der kalder medarbejderne sig for tekstforfattere, og det gjorde de allerede, inden story telling kom til Danmark." Studentens fortvivlelse skyldes den forestående sommereksamen. Han har besluttet at skrive opgave om, hvad litteratur er. Jeg skal ikke kunne sige, hvor den idé er kommet fra. Jeg kender ham kun som agitator for den holdning, at hvis bare begreberne virker, er det nok; vi behøver ikke filosofi. Lidt tænkning havde dog næppe skadet, inden han besluttede at kaste sig over det filosofiske spørgsmål om litteraturens væsen. Men det er ikke min opgave at stikke ham min overlegenhed $\mathrm{i}$ øjnene. Jeg skal derimod redde ham gennem de værste skær. "Hør engang," siger jeg til studenten, mens jeg tænker, at han bliver helt tiltalende af at være tvunget til at slå ørerne ud. "Kender du Heideggers Aufenthalte," spørger jeg vel vidende, at det er mere usandsynligt end sne i Sahara. "Det er en lille bog, som han tilegnede sin kone, Elfride, på hendes 70 års fødselsdag. En rejseskildring skrevet efter deres første rejse til Grækenland." "Hmm," siger studenten skeptisk, men han er begavet nok til at ane, at dette har noget med litteratur at gøre - og dermed også med hans eksamen. "Rejsen til Grækenland var en gave fra Elfride til Heidegger, som han længe undveg," fortsætter jeg. "Ja, det er filosofien i en nøddeskal," ryger det ud af studenten. "Den komplicerer det hele. Hvorfor tog han ikke bare af sted, når nu konen betalte gildet?" "Betalte og betalte," svarer jeg, "om de var så moderne, skal jeg ikke kunne sige. Men gaven krævede sin ret, som Heidegger skriver, og i foråret 1962 lagde de fra kaj i Venedig for at sejle til Peleponnes, Kreta og Rhodos, hvorefter de satte over Det Egæiske Hav for at komme til Athen, Ægina og Delphi.” Jeg tænker mig om et øjeblik og siger så, "Det er i øvrigt et interessant spørgsmål, du tager op. Hvad frygtede Heidegger, der selv kredsede om inspirationen fra den førsokratiske filosofi? Det fortæller han faktisk i bogen. Han var bange for ikke at erfare Grækenlands oprindelige sjæl og for at se sine tanker om det græske gjort til skamme." "Nå ja, det var vel heller ikke helt usandsynligt," indskyder studenten. Men han griner også skævt; han er godt klar over, at han leger med ilden. Jeg sender ham et blik, der ikke lader ham dø i synden, og fortsætter: "Heidegger havde denne her frygt, og den forlader ham ikke, da de lægger fra kaj i Venedig. En by, der i øvrigt ikke imponerer ham. Den har ingen "vejvisende kraft", som han siger, for den er forfaldet til museum. Men at ankomme til Korfi hjælper heller ikke, for øens landskab virker italiensk, og det lader ikke "det anede og forventede" indfinde sig. Så da de rejser videre, er Heidegger stadig naget af "spørgsmålet om, hvorvidt det overhovedet er muligt at erfare "det oprindelige græske". Måske kan det slet ikke lade sig gøre, fordi man altid har sin egen horisont med i bagagen? Måske er ethvert forsøg på at "genvinde begyndelsen" dømt til at mislykkes? Og måske fordærver den slags eftertanke den umiddelbare erfaring, og man burde bare fastholde det sete $\mathrm{i}$ ren og skær beskrivende fortælling?" Jeg holder en kunstpause for at se, om studenten har fanget vinket, men så let går det ikke. 
"Han er inde på noget der," siger studenten. "Dette der med, at man spænder ben for bare at opleve verden, når man skal tænke over alting." "Lad os vende tilbage til det senere," svarer jeg. Det var mere Heideggers overvejelse over fortælleformen, der var pointen, og studentens sammenblanding af oplevelse og erfaring begejstrer mig heller ikke. "Heidegger og Elfride rejser videre til Olympia, hvor hans forventninger blusser op igen," fortsætter jeg. " $\mathrm{Nu}$ må det komme, skriver han. Her hvor hele Grækenland engang forsamledes på hede sommerdage for at fejre gùderne, må landet vise sit sande ansigt. Men også Olympia skuffer, for stedets skulpturer lader ganske vist noget ane, men de står ikke $\mathrm{i}$ et tempel, sådan som statuer oprindeligt gjorde, derimod i et museum, og heller ikke i Olympia giver landskabet noget indblik i det særegne ved den græske verden. Tværtimod undrer Heidegger sig over, hvordan dette landskab, der kunne have ligget i Italien, har kunnet være det væsentligste feststed i Grækenland." "Feststed?," spørger studenten. "Ja, det var her, de største guder blev fejret. Festen udspringer oprindeligt af kulten", svarer jeg. "Men lad os komme videre. Der står en hel kø af studerende udenfor, som jeg også skal tale med i dag," siger jeg og fortsætter: "Heidegger skriver selv i sin rejseskildring, at det græske fortsat blot er en forventning, en anelse eller $i$ værste fald et produkt af hans egen fantasi, og når man læser bogen, fảr man indtryk af, at der ingen ende er på de skuffelser, som han oplever. Ved synet af Epidauros udbryder han f.eks., idet han citerer Hölderlin, "Hvorfor tier det også, det gamle hellige teater?" Kretas minoiske kultur bringer ham heller ikke nærmere det græske, men åbner derimod en helt anden verden, og med sin beliggenhed ved den lilleasiatiske kyst fører Rhodos måske endnu længere bort fra det græske." "Men nu sker der noget," siger jeg, “for måske forholder det sig omvendt. Måske er det netop her, i mødet med Asien, hvis lidenskab grækerne forsonede i noget større, som Heidegger skriver, at det hele tager en ny drejning $i$ hans fortælling, ligesom historien gjorde $\mathrm{i}$ virkeligheden." Jeg kigger igen undersøgende på studenten. Det er ikke til at se, om han har opfanget nøgleordet i denne ombæring. Spændingen har grebet ham, og nu vil han bare høre, hvordan det ender. "På dette her punkt i fortællingen," siger jeg, idet jeg fremhæver det sidste ord, "er Heidegger så desillusioneret, at han forsømmer de muligheder, som rejsen rummer. Han bliver på skibet, sover fra det hele; måske har han endelig opgivet at søge. Men så sker underet - ved ankomsten til Delos, “øernes $\varnothing "$. Heideggers forventning går i opfyldelse; han erfarer det oprindelige græske." “Okay!," siger studenten opstemt, "og hvad er det så?" "Ja, det er ikke sådan til at sige," svarer jeg, "for det skal erfares. Men Heidegger skriver $i$ hvert fald, at resten af rejsen tager form som et "ophold", en "oplyst dvælen ved det, som alétheia er". På resten af turen er hans tanker viet spørgsmålet om menneskets muligheder for den slags ophold. Dvæler vi i vor tilværelse ved det væsentlige, eller undgår vi det derimod? Det er på grund af denne erfaring og de tanker, som den vækker, at han om hjemrejsen over Adriaterhavet skriver, at den tager form som én stor tak for "opholdets gave og indblikket i dets væsen". Heidegger takker ikke for at have oplevet Grækenland. Han takker for at have fảet lov til at opholde sig i det græske, og hans tak tager form som kontemplation." Det sidste er sikkert for stor en mundfuld for studenten. Noget forvildet ser han i hvert fald ud, men det er lykkedes at bryde igennem og fange hans opmærksomhed. Barrikaderne er faldet, og jeg benytter lejligheden til at koble tilbage til hans opgave. "Hvad er litteratur?, spurgte du. Er denne her rejseskildring litteratur?," spørger jeg studenten, som imidlertid ikke aner, hvad han skal svare. "Den kunne godt minde om en spændingsroman," siger han til sidst. "Jeg blev $i$ hvert fald helt grebet, og der var også nærmest en spændingskurve i fortællingen. Først blev vi præsenteret for den søgen, som Heidegger rejste til Grækenland med, og dernæst gik det galt, den ene gang efter den anden, han blev mere og mere skuffet, indtil han nærmest gik i sort. Men netop som det ikke kunne blive værre, vendte det hele. Så skete underet, som du sagde. Det minder mig om den peripeti, du talte om, da vi gennemgik Aristoteles' poetik. Det skæbneomslag i den græske tragedie, som er forudsætningen for, at det hele ender i katharsis." "Ja," siger jeg, "den rejse- 
skildring er litteratur. Heidegger kunne have skrevet den uden at have sat sin fod i Grækenland, for der er tale om en konstruktion. Det betyder ikke, at fortællingen ikke rummer erfaring, men denne rejseskildring er netop en fortælling. Den er kendetegnet ved det, der ifølge Aristoteles adskiller poesi fra historie: Heidegger beretter ikke bare, "hvad der er sket". Han fortæller derimod, "hvordan det skete måtte være for at ske". Han gengiver ikke bare det partikulære, der er hændt fra dag til dag, men uddrager derimod noget alment af det og præsenterer dette for sin læser. Heideggers rejseskildring er derfor mere filosofisk, end en historisk beretning ville have været, nøjagtig som Aristoteles siger om poesien sammenlignet med historien. Men teksten er ikke et filosofisk tankeværk, derimod et æstetisk litteraturværk, for den måde, Heidegger konstruerer sin fortælling, har en bestemt form. Som du selv er inde på, låner han fra den klassiske tragedie eller nærmere bestemt fra dens moderne slægtninge, f.eks. udviklingsromanen." Her bliver jeg imidlertid forstyrret af køen uden for min dør. To af de utålmodige er kommet op at skændes om, hvem der har mest krav på min tid - hende med specialet, der trækker ud, eller ham med den uopsættelige ansøgning om stipendium. Jeg beroliger gemytterne med en udvidelse af træffetiden og beslutter at gå linen ud og give studenten den fulde forelæsning. En slags tak skal han have for at have overgivet sig. "Vi nåede til, at Heideggers rejseskildring er et litterært værk," siger jeg til ham. "Den er altså ikke et filosofisk værk, som handler om poesi, sådan som mange andre af hans skrifter. Den er derimod et litterært værk, men dens indhold - det er til gengæld filosofisk. For hvad handler denne rejseskildring om? Ikke om Heidegger selv og slet ikke om to per- soner, der er på ferie i Grækenland, men derimod om tænlningen. Heideggers rejseskildring er for så vidt en ny Åndens fanomenologi i litterær form. En tankens dannelsesroman, der ligesom Hegels værk ender lykkeligt, nemlig i den undrende beundring af det erkendte, som Heidegger omtaler som en taksigelse. Fortællingen om rejsen til Grækenland, der fører til et ophold i det græske, kulminerer med andre ord i tankens fest, kontemplationen af det højeste, som er selve det under, at det er menneskeligt muligt at erfare alétheia." "Temaet er håb og taknemlighed," siger jeg. "Håbet om at erfare sandheden og taknemligheden over dermed at kunne tænke noget væsentligt. Dette litterære værks filosofiske tema er således den tænkning, den egentlige, som forudsætter noget andet end oplevelser, f.eks. turisters oplevelser af seværdighederne på rejsemålet. Som derimod kræver erfaring af det egentlige, f.eks. den rejsendes indsigt $\mathrm{i}$ ånden $\mathrm{i}$ den kultur, som han besøger. Som det fremgår af Heideggers skildring, er denne erfaring kun mulig, hvis man åbner sig for den dimension af venten og forventning, der er poesiens element, men som ikke er forbeholdt den alene. Filosofien har også adgang til denne dimension, og når det sker, indfinder underet sig, og tankens fest kan begynde." Jeg betragter studenten, der er faldet $i$ staver. Han har tydeligvis glemt alt om, at begreber bare skal virke; ser derimod ud til at være begyndt at reflektere. Ikke uden håb afslutter jeg derfor seancen med en opfordring om at gå hjem og gøre klar til fest. "Den rigtige, forstås," siger jeg for ikke at tabe det hele på gulvet. “Og så kommer du tilbage igen, når du har festet nok til at kunne forklare, hvorfor du ikke kan undvære filosofi. Derefter kan vi tage hul på spørgsmålet om litteraturens væsen." 